\title{
НЕФТЬ И ЭКОНОМИКА СТРАН БРИКС
}

\author{
(c) 2020 Гусарова Светлана Анатольевна \\ доктор экономических наук, доцент, ведущий научный сотрудник \\ Российский экономический университет имени Г.В. Плеханова, Россия, Москва \\ E-mail: s-gusarova@mail.ru
}

Автор провел исследование влияния импорта и экспорта нефти на развитие экономик стран БРИКС. Сделан вывод, что участие в мировой торговле нефтью оказывает наибольшее влияние на рост экономики Бразилии, Китая и России. На рост ВВ Индии этот процесс оказывает среднее значение и практически не оказывает влияние на развитие экономики ЮАР. Раскрыты проблемы нефтяного бизнеса в условиях пандемии.

Ключевые слова: добыча нефти, мировая торговля нефтью, страны БРИКС, развитие экономики.

\section{1. Введение}

В настоящее время нефть остается основным энергетическим ресурсом мировой экономики, несмотря на развитие и внедрение новых альтернативных, возобновляемые источников энергии. Изменение нефтяных котировок оказывает большое влияние на развитие всех стран в мире, влияет на приток валютных ценностей. Страны-экспортеры нефти заинтересованы в росте нефтяных котировок, в то время, как страны-импортеры - наоборот, предпочитают их снижение. Сокращение нефтяного производства ведет к росту цен на этот энергоресурс, а увеличение добычи нефти - к снижению ее котировок. Ведущими мировыми экспортерами нефти являются Россия, страны Ближнего и Среднего Востока, США, Канады. Отрицательное влияние перепады нефтяных цен оказывают на экономику многих стран, особенно развивающихся государств, в том числе стран БРИКС.

\section{2. Мировые запасы нефти}

Доказанный мировой запас нефти в 2018 году составил 1729,7 млрд. баррелей (на 15,8\% больше 2008 года). Наибольший объем доказанных запасов нефти в глобальной экономике в 2018 году был в Венесуэле - 303,3 млрд. баррелей (17,5\% мирового объема), на втором месте была Саудовская Аравия - 297,7 млрд. баррелей $(17,2 \%)$. на третьем - Канада - 167,8 млрд. баррелей $(9,7 \%)$, на четвертом - Иран - 155,6 баррелей (9,0\%), на пятом - Ирак - 147,2 млрд. баррелей $(8,5 \%)$, и на шестом месте была Россия - 106,2 млрд. баррелей (6,1\%) (Рисунок 1).

Общий объем доказанных запасов нефти в странах БРИКС составил в 2018 году 150 млрд. баррелей, в том числе в России - 106,2 млрд. баррелей, в Китае - 25,9 млрд. баррелей $(1,5 \%$ мирового объема), в Бразилии - 13,4 млрд. баррелей $(0,8 \%)$, в Индии $-4,5$ млрд. баррелей $(0,3 \%)$ (Рисунок 2). ЮАР в список ведущих стран, обла-

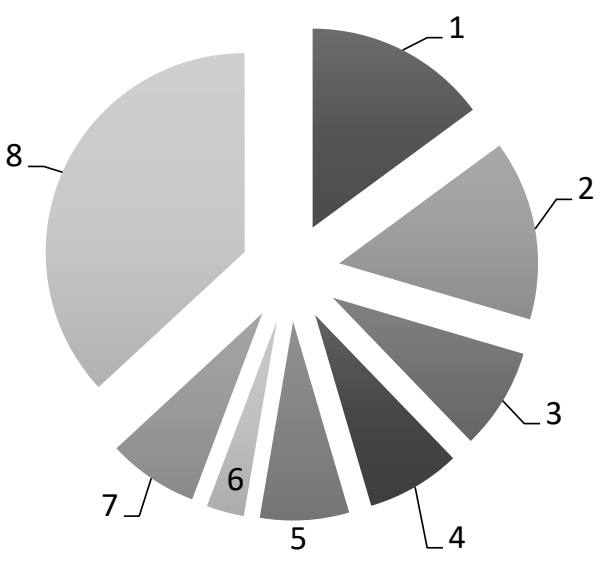

\author{
1. Венесуэла \\ 2. Саудовская Аравия \\ 3. Канада \\ 4. Иран \\ 5. Ирак \\ 6. США \\ 7. БРИК \\ 8. Другие
}

Рисунок 1. Доказанные запасы нефти в глобальной экономике в 2018 году, млрд. баррелей [2, С. 13] 


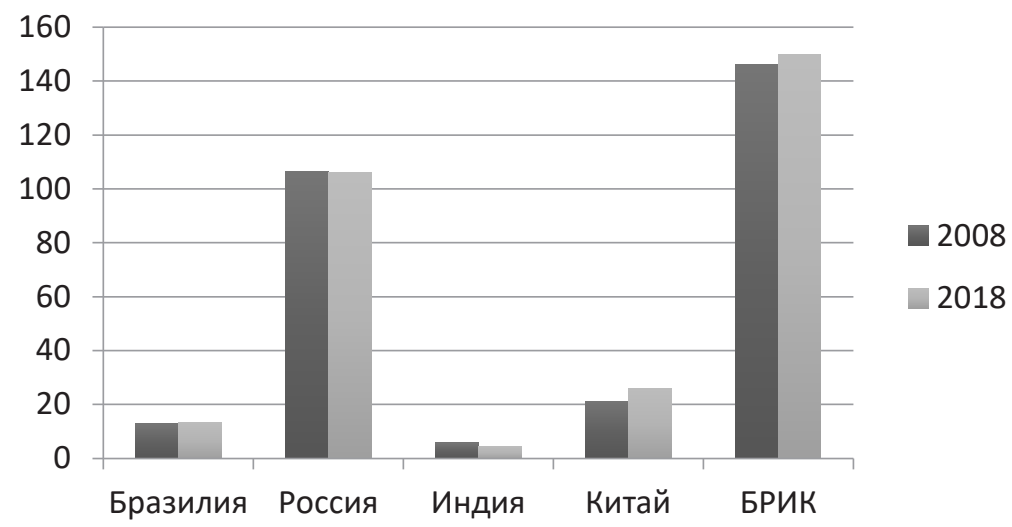

Рисунок 2. Доказанные запасы нефти стран БРИК за 2008-2018 годы, млрд. баррелей [2, С. 13]

дающих значительным объемом доказанных запасов нефти не попала. Китай и Индия вошли в этот список, несмотря на сложившееся мнение, что эти страны заинтересованы в импорте нефти, но не обладают ее значительными запасами. Доказанные запасы нефти Китая увеличились за 10 лет на $22,2 \%$.

\section{3. Добыча нефти в глобальной экономи-} ке

Основной нефтедобывающей страной в мире в 2018 году были США, добывавшие 15,3 млн. баррелей в сутки (или 16,2\% объема добычи нефти в глобальной экономике), опередив Саудовскую Аравию (12,3 млн. баррелей в сутки, или 13\% мировой добычи нефти) и Россию $(11,4$ млн. баррелей в сутки, или $12,1 \%$ мировой добычи нефти).

Среди стран БРИКС, кроме России, добычей нефти занимались Китай, добывавший в 2018 году 3,8 млн. баррелей в сутки (4\% мировой добычи), Бразилия - 2,9 млн. баррелей в сутки $(2,8 \%)$ и Индия - 0,9 млн. баррелей в сутки (0,9\%). На долю стран БРИКС приходится 19,8\% мировой добычи нефти (Рисунок 3).

В 2020 году на фоне пандемии коронавируса разразилась «нефтяная война» между Саудов- ской Аравией и Россией. Проблемы в картеле OПЕК+, связанные с решением наращивания добычи нефти и несогласием с этим решением России, привели к аннулированию предыдущих договоренностей. 1 апреля 2020 года сделка, заключенная ОПЕК+ в 2016 году по сокращению объемов добычи нефти, и позволяющая удерживать нефтяные котировки в районе 50 долларов США за баррель, прекратила свое действие. Увеличение объемов добычи нефти странами ОПЕК привело к резкому снижению котировок нефти, что в свою очередь повлияло на обвал мировых биржевых индексов и на значительное укрепление доллара США. Например, на Нью-Йоркской фондовой бирже (NYSE) 12 марта 2020 года были остановлены торги в связи с тем, что ключевой индекс биржи (DJIA) снизился на 9,33\%.

Это повлияло и на снижение биржевых индексов в странах БРИКС. Индекс РТС (Российской торговой системы) 12 марта 2020 года снизился за месяц почти на 1000 пунктов (до 966,40 пунктов) [1]. Индекс фондовой биржи Сан-Паулу (IBOVESPA) является основным фондовым индикатором Бразилии уменьшился к 12 марта (за месяц) в 1,6 раз до 72582,53 пунктов [4]. Индекс Шанхайской фондовой биржи (SSE Composite) снизился за два месяца в 1,2 раза

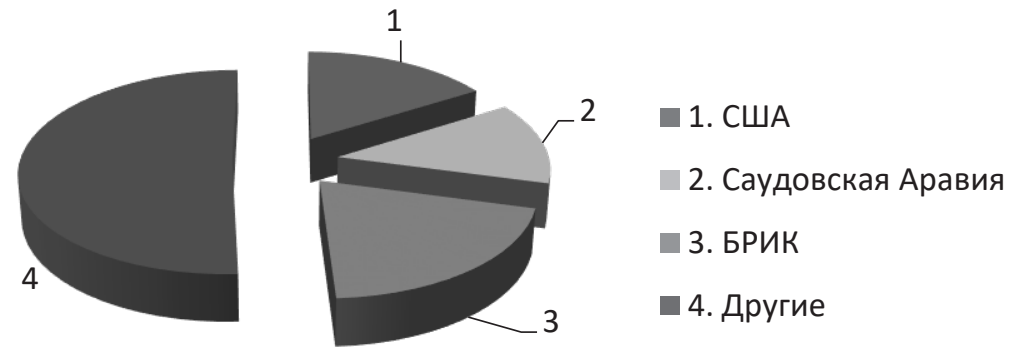

Рисунок 3. Объем добычи нефти в некоторых странах мира, тысяч баррелей в сутки [2, С. 16] 
(до 2660,17 пунктов 23 марта) [6]. Основным индикатором фондового рынка Индии является индекс Бомбейской фондовой биржи (BSE Sensex 30). За месяц этот индекс снизился в 1,6 раза до 25981,24 (23 марта) [7].

На снижение европейских биржевых котировок повлияло известие о том, что компания из Саудовской Аравии (Saudi Aramco) планирует осуществить нефтяную экспансию в Европе.

Для восстановления баланса на мировом рынке нефти по инициативе Саудовской Аравии 9 января 2020 года состоялась новая встреча ОПЕК+. Сделка была завершена 10 января 2020 года (на встрече G20). В результате было принято решение о постепенном снижении объемов добычи нефти до середины весны 2022 года. С 1 мая до конца июня 2020 года ежедневный объем добычи нефти будет снижен на 10 млн. баррелей. Затем объемы снижения добычи нефти будут изменяться: с 1 июля 2020 года - на 8 млн. баррелей в сутки, с января 2021 года до апреля 2022 года - на 6 млн. баррелей в сутки. Россия и Саудовская Аравия сократят добычу нефти на 2,5 млн. баррелей в сутки каждая. Объем добычи нефти странами ОПЕК+ будет снижен на $23 \%$. На эти условия сокращения добычи нефти не согласилась Мексика, которой придется снизить добычу на 400 тысяч баррелей в сутки. Договоренность вступит в силу, только после присоединения к сделке Мексики. В дальнейшем к сделке могут присоединиться США, Канада и Норвегия, несмотря на то, что он и не входят в состав картеля ОПЕК+ [5].

\section{4. Объемы переработки нефти в разных странах мира}

Важное значение для развития экономик стран мира имеет не только наличие запасов нефти и объемы ее добычи, но и переработка нефти и производство нефтепродуктов. Ведущей страной-производителем нефтепродуктов в мире в 2018 году были США - 17 млн. баррелей в сутки (20,4\% мирового производства). На втором месте был Китай - 12,4 млн. баррелей в сутки (15\% мирового производства), третье место занимала Россия $-5,8$ млн. баррелей в сутки (7\%), четвертое место - Индия - 5,2 млн. баррелей в сутки (6,2\%). Бразилия была на девятом месте в мире по производству нефтепродуктов 1,7 млн. баррелей в сутки (2,1\%). На долю стран БРИК в целом пришлось 30,3\% мирового производства нефтепродуктов (Рисунок 4).

Что касается стран, обладающих наибольшими объемами доказанных запасов нефти, то они не уделяют большое внимание ее переработке. По этому показателю доля Саудовской Аравии составила 3,3\% мирового производства нефтепродуктов, Ирана $-2,4 \%$.

\section{5. Влияние экспорта и импорта нефти} на экономику стран

Ведущим мировым импортером нефти в 2018 году был Китай - 11,0 млн. баррелей нефти в сутки (15,5\% мирового импорта). Второе место занимали США - 9,9 млн. баррелей в сутки $(13,9 \%)$, на третьем месте была Индия - 5,2 млн. баррелей нефти в сутки (7,3\%), на четвертом Япония - 3,9 млн. баррелей (5,5\%). На 2 страны из группы БРИКС приходилось $22,8 \%$. Доля четырех ведущих стран-импортеров нефти была $42,2 \%$ мирового импорта нефти.

В 2018 году первое место среди стран-экспортеров нефти занимала Россия - 9,3 млн. баррелей нефти в сутки (12,8\% мирового экспорта), на втором месте была Саудовская Аравия - 8,6 млн. баррелей в сутки (12\%), на третьем - США 7,1 млн. баррелей в сутки (10\%), на четвертом Канада $-4,5$ млн. баррелей в сутки (6,3\%). Доля

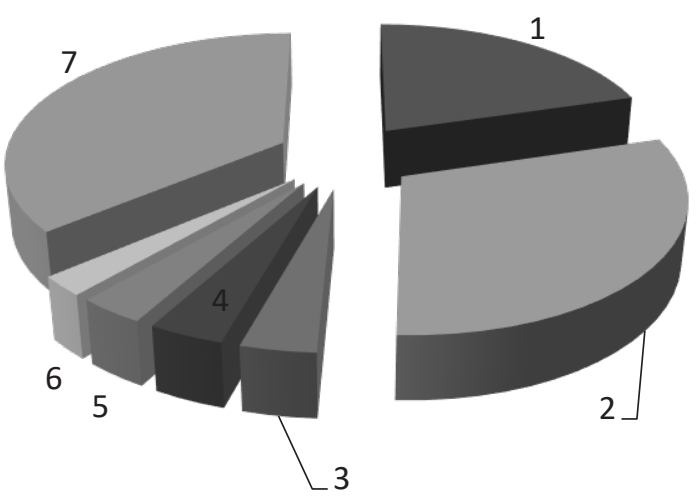

\author{
1. США \\ 2. БРИК \\ ․ Япония \\ 4. Южная Корея \\ 5. Сайдовская Аравия \\ 6. Иран \\ 7. Другие
}

Рисунок 4. Доля объема переработки нефти в некоторых странах мира,\% [2, С. 26] 
четырех ведущих стран-экспортеров нефти составляла $41,1 \%$ мирового экспорта нефти.

Для того, чтобы определить, как экспорт и импорт нефти влиял на развитие экономик некоторых стран БРИКС нами был проведен регрессионный анализ за 2008-2018 годы, который позволил рассчитать для стран БРИКС следующие уравнения регрессии [3; 8]:

- Бразилия у $=29.5529 \mathrm{x}_{1}+132.4042$

- Россия $\mathrm{y}=8.2454 \mathrm{x}_{1}+639.7151$

- Индия $\mathrm{y}=1.5844 \mathrm{x}_{1}+1867.2686$

- Китай $\mathrm{y}=31.793 \mathrm{x}_{1}+3907.7239$

- ЮАР y $=0.2024 \mathrm{x}_{1}+299.8786$

\section{6. Выводы}

Проведенное исследование позволило сделать вывод, что увеличение объема товарооборота нефти Бразилии на 1 долл. приводит в среднем к повышению объем его ВВП на 29,6 долл. В России этот показатель был 8,2 долл., в Индии 1,6 долл., в Китае - 31,8 долл., в ЮАР - 0,2 долл.

На глобальную экономику, в том числе стран БРИКС в настоящее время, большое влияние оказывают следующие процессы: а) пандемия, разразившаяся в начале 2020 года, в результате которой произошла остановка деятельности некоторых секторов экономики многих стран мира; б) проблемы в картеле ОПЕК+ («ценовая война» между Россией и Саудовской Аравией, приведшая к резкому снижению цен на нефть); в) переполнение запасов нефти в хранилищах в глобальной экономике; г) замедление темпов роста глобальной экономики повлияло на снижение потребностей в энергоресурсах многих стран мира, в первую очередь Китая; д) снятие эмбарго с Ирана привело к притоку на глобальный рынок иранской нефти не только благодаря увеличению ее добычи, но и из нефтяных хранилищ.

Принятое решение о сокращении объемов добычи нефти позволит сгладить неопределенность, снизить волатильность, стабилизировать мировые финансовые и энергетические рынки, что в свою очередь, окажет положительные влияние на развитие всех стран в глобальной экономике, в том числе стран БРИКС.

В настоящее время Китай, раньше других стран справившись с коронавирусом, разрабатывает план выхода из экономического торможения. Понимая, что экономические проблемы грозят всем странам, многие иностранные компании остановили вывод своих производств из Китая, а некоторые вернулись в Китай. КНР возобновил промышленное производство, закупив 1,6 млн. тонн российской нефти марки Urals.

Экономика России находится в состоянии двойного шока. С одной стороны, из-за пандемии сократились глобальные потребности в нефти, следовательно, сократился объем добычи и экспорта нефти и нефтепродуктов Россией. А с другой стороны, в марте 2020 года произошло резкое сокращение размера нефтяных котировок. Кроме того, на развитие российского сектора углеводородов продолжают оказывать отрицательное влияние санкции США и ряда европейских стран, влияющих на приток прямых иностранных инвестиций в этот сектор экономики.

\section{Библиографический список}

1. Индекс PTC (IRTS) [Электронный ресурс] // Investing.com. - Режим доступа: https://ru.investing.com/indices/ rtsi (дата обращения: 08.04.2020).

2. BP Statistical Review of World Energy 2019 [Электронный ресурс] / Energy Outlook // BP p.l.c.- Режим доступа: https:/www.bp.com/content/dam/bp/business-sites/en/global/corporate/pdfs/energy-economics/statisticalreview/bp-stats-review-2019-full-report.pdf (дата обращения: 08.04.2020).

3. GDP, current prices / World Economic Outlook (April 2019) // International Monetary Fund.- URL: http:// www.imf.org/external/datamapper/NGDPD@WEO/OEMDC/ADVEC/WEOWORLD (accessed: 02.04.2020).

4. IBOVESPA [Электронный ресурс] // Yahoo! Finance.- Режим доступа: https://finance.yahoo.com/ quote/\%5Ebvsp?ltr=1 (дата обращения: 08.04.2020).

5. Saudi, Russia work oil cut deal in G20 talks, seek U.S. participation [Электронный pecypc] // Reuters. - Режим доступа: https://www.reuters.com/article/us-global-oil-g20-energy/saudi-russia-work-oil-cut-deal-in-g20-talksseek-u-s-participation-idUSKCN21S19K (дата обращения: 10.04.2020).

6. SSE Composite Index [Электронный ресурс] // Yahoo! Finance.- Режим доступа: https://finance.yahoo.com/ quote/000001.SS/ (дата обращения: 10.04.2020).

7. S\&P BSE SENSEX [Электронный ресурс] // BSE.- Режим доступа: https://www.bseindia.com/sensex/code/16/ (дата обращения: 10.04.2020).

8. UNCTADSTAT [Электронный ресурс].- Режим доступа: http://unctadstat.unctad.org/wds/TableViewer/ tableView.aspx (дата обращения: 02.06.2018). 